Check for updates

Cite this: RSC Adv., 2019, 9, 6770

Received 23rd December 2018 Accepted 16th February 2019

DOI: $10.1039 / c 8 r a 10525 a$

rsc.li/rsc-advances

\title{
tert-Butylphenylthiazoles with an oxadiazole linker: a novel orally bioavailable class of antibiotics exhibiting antibiofilm activity $\dagger$
}

\author{
Ahmed Kotb, $\dot{+}^{a}$ Nader S. Abutaleb, $\dot{\dagger}^{\mathrm{b}}$ Mohamed Hagras, ${ }^{a}$ Ashraf Bayoumi, ${ }^{a}$ \\ Mahmoud M. Moustafa, ${ }^{C}$ Adel Ghiaty, ${ }^{a}$ Mohamed N. Seleem ${ }^{\star b d}$ \\ and Abdelrahman S. Mayhoub iD *ae
}

\begin{abstract}
The structure-activity and structure-kinetic relationships of a new tert-butylphenylthiazole series with oxadiazole linkers were conducted with the objective of obtaining a new orally available antibacterial compounds. Twenty-two new compounds were prepared, purified and identified. Their activity against methicillin-resistant Staphylococcus aureus were examined. Compound 20 with 3-hydroxyazetidine as a nitrogenous side chain showed promising activity against twenty-four clinical isolates, including vancomycin-resistant staphylococcal and enterococcal species with MIC values ranging from 4-8 $\mu \mathrm{g}$ $\mathrm{mL}^{-1}$. Additional advantages of this compound include an ability to eradicate staphylococcal biofilm mass in a dose-dependent manner as well as high metabolic stability after an oral dose of $25 \mathrm{mg} \mathrm{kg}^{-1}$ with a biological half-life that exceeds 5 hours and a plasma concentration $\left(C_{\max }\right)$ that exceeds the MIC values.
\end{abstract}

\section{Introduction}

The rapid development of antimicrobial resistance is a major global health concern due to the exponentially decreased utility of antibiotics available for clinicians. The World Health Organization (WHO) recently reported a set of innovation criteria for new antibiotic developments in order to maintain long-term clinical efficacy. ${ }^{1}$ These criteria include introducing novel chemical scaffolds, broad spectrum activity versus multidrug-resistant strains, and targeting novel pathways. ${ }^{1}$ These criteria are met by our newly-developed arylthiazole 1a, as an inhibitor of two novel proteins (undecaprenyl pyrophosphatase and undecaprenyl pyrophosphate synthase) involved in the peptidoglycan synthesis. ${ }^{2-5}$ However, the main drawback of 1a (Fig. 1) was the extremely short plasma halflife, for which the $t_{1 / 2}$ was only 29 minutes. ${ }^{5}$ The benzylic

${ }^{a}$ Department of Pharmaceutical Organic Chemistry, College of Pharmacy, Al-Azhar University, Cairo 11884, Egypt. E-mail: amayhoub@azhar.edu.eg

${ }^{b}$ Department of Comparative Pathobiology, College of Veterinary Medicine, Purdue University, West Lafayette, IN, USA 47907. E-mail: mseleem@purdue.edu

${ }^{c}$ Department of Pharmaceutical Chemistry, Imam Abdulrahman Bin Faisal University, Dammam 31441, Saudi Arabia

${ }^{d}$ Purdue Institute of Inflammation, Immunology, and Infectious Disease, West Lafayette, IN, USA, 47907

${ }^{e}$ University of Science and Technology, Nanoscience Program, Zewail City of Science and Technology, October Gardens, 6th of October, Giza 12578, Egypt

$\dagger$ Electronic supplementary information (ESI) available: Scanned copies of all spectral data of all new reported compounds. See DOI: 10.1039/c8ra10525a

\$ These two authors contributed equally. methylene carbon was identified as a metabolic soft spot. ${ }^{6}$ The replacement of the $n$-alkyl moiety with branched tert-butyl or alkoxy analogues provided more metabolically-stable derivatives with enhanced antibiofilm activity. ${ }^{6,7}$ We did additional structural modification focused on the $\mathrm{C}=\mathrm{N}$ linker, where it has been replaced with different heterocyclic rings. ${ }^{1}$ of the tested heterocyclic linkers, ${ }^{\mathbf{4}, 5,8}$ only the oxadiazole-containing derivatives were orally bioavailable. ${ }^{1}$

In this study, we address the structure-activity and structurekinetic relationships of the oxadiazole based hybrid scaffold $\mathbf{1 b}$ at position-5 (Fig. 1), aiming to prepare new derivatives with enhanced antibacterial activity against multidrug-resistant staphylococcal strains, improved oral bioavailability and antibiofilm activity.

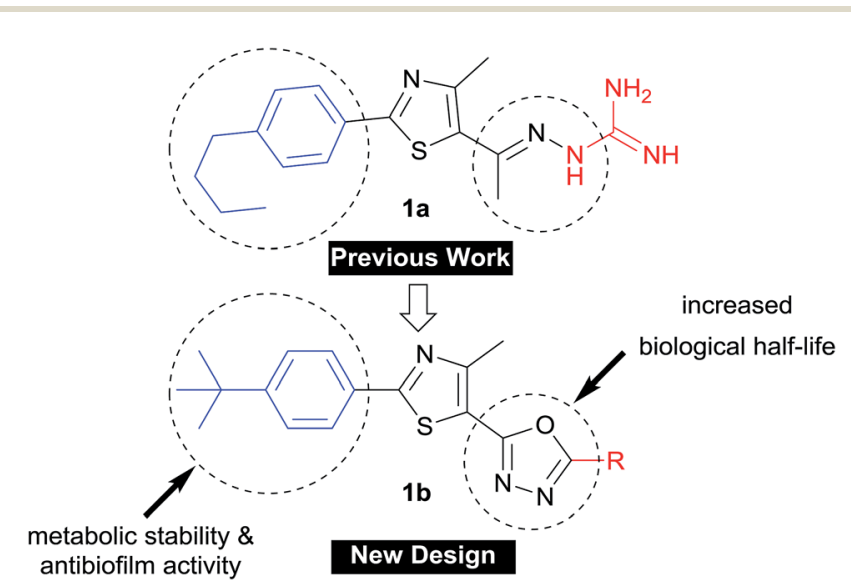

Fig. 1 Progress in the development of phenylthiazole antibiotics. 


\section{Results and discussion}

\subsection{Chemistry}

The synthesis of the target compounds started with the preparation of phenylthiazole ethyl ester 3 from commercially available thioamide 2 . The treatment of ethyl ester 3 with hydrazine hydrate provided the corresponding acid hydrazide 4 , which was converted into methylmercapto-1,3,4-oxadiazole upon reaction with carbon disulfide followed by the methylation of the free mercaptyl group with dimethyl sulphate (Scheme 1). The oxidation of the methylmercaptyl moiety with chloroperbenzoic acid furnished the key intermediate 7, which was then utilized to prepare the entire series of oxadiazolylphenylthiazole final products 8-30.

The chemical structures of the newly synthesized compounds were confirmed via spectral and elemental data. For instance, the ethoxy group of compound 3 was represented in the ${ }^{1} \mathrm{H}$ NMR spectrum by two signals at 4.33 and $1.13 \mathrm{ppm}$. These two distinguished signals were replaced with two broad singlets at $\delta 9.57$ and 4.54 when treated with hydrazine hydrate (compound 4). Upon cyclization with carbon disulfide and

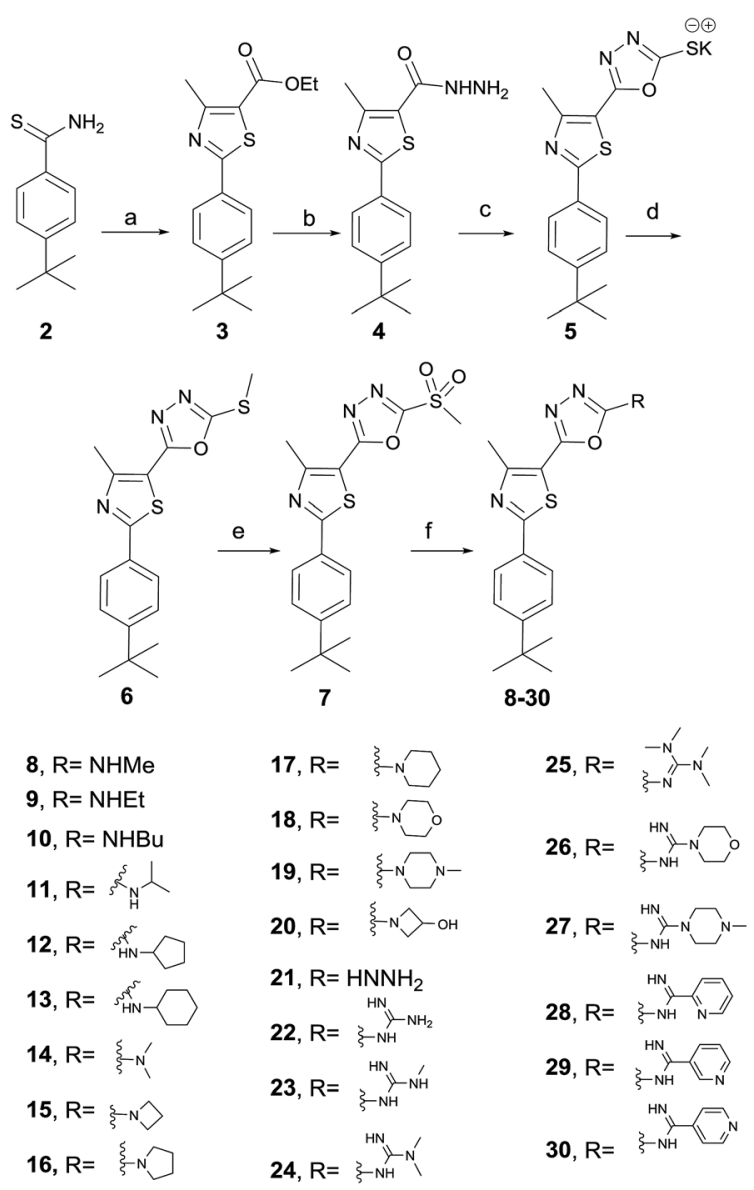

Scheme 1 Synthesis of compounds 8-30. Reagents and conditions: (a) ethyl 2-chloro-3-oxobutanoate, absolute $\mathrm{EtOH}$, heat at reflux, $4 \mathrm{~h}$, (b) absolute $\mathrm{EtOH}, \mathrm{NH}_{2} \mathrm{NH}_{2} \cdot \mathrm{H}_{2} \mathrm{O}$, heat at reflux, $8 \mathrm{~h}$; (c) $\mathrm{CS}_{2}, \mathrm{KOH}$, $\mathrm{EtOH}$, heat reflux, $12 \mathrm{~h}$; (d) dimethyl sulfate, $\mathrm{H}_{2} \mathrm{O}$, stirring at $23^{\circ} \mathrm{C}, 2 \mathrm{~h}$; (e) $m C P B A$, dry $D C M, 23{ }^{\circ} \mathrm{C}, 16 \mathrm{~h}$; (f) appropriate amine, hydrazine, guanidine or carboximidate; $\mathrm{K}_{2} \mathrm{CO}_{3}, \mathrm{DMF}$, heat at $80^{\circ} \mathrm{C}$ for $0.5-12 \mathrm{~h}$. methylation with dimethylsulfate, the broad signals disappeared and an additional singlet signal in the aliphatic region, appeared at $\delta 2.77$, a characteristic of $S$-methyl (compound 5). Upon oxidation with $m \mathrm{CPBA}$ (compound 6), this particular signal shifted downfield to $3.47 \mathrm{ppm}$, and disappeared following the treatment of 6 with nitrogenous based nucleophiles. Among compounds 7-12, the characteristic methylsulfonyl moieties signal at $3.47 \mathrm{ppm}$ disappeared from the ${ }^{1} \mathrm{H}$ NMR spectra and was replaced with a broad singlet at approximately 7.83 ppm due to the NH group as well as the presence of extra aliphatic protons equivalent to the number of aliphatic side chains connected with the terminal amine. Collectively, these findings confirm the tethering of the nucleophile moiety with the oxadiazole position-5. For example, the ${ }^{1} \mathrm{H}$ NMR spectrum of compound 10 showed, in addition to the oxadiazolylphenylthiazole nucleus protons, a broad singlet signal equivalent to one proton at $\delta 7.82$ due to $\mathrm{NH}$ in addition to a multiplet signal equivalent to one proton and a doublet signal for six protons at $\delta 3.70$ and 1.20 , respectively, due to an isopropyl side chain. For the tertiary-amine side-chain-containing compounds 13-19, the most predominant features of the ${ }^{1} \mathrm{H}$ NMR isolated products spectra were the disappearance of the methylsulfonyl singlet at $3.47 \mathrm{ppm}$ and the appearance of a set of distinctive signals in the upper field region due to the corresponding protons of the alkyl nucleophile moieties. On the other hand, the hydrazinyl group of compound 20 was represented in the ${ }^{1} \mathrm{H}$ NMR by two broad singlets at 6.94 and $4.54 \mathrm{ppm}$, due to $\mathrm{NH}$ and $\mathrm{NH}_{2}$ moieties, respectively.

Additionally, the ${ }^{1} \mathrm{H}$ NMR spectrum of the guanidinecontaining derivative 21 displayed two broad singlets at 7.21 and $7.06 \mathrm{ppm}$ due to guanidine protons, as well as signals corresponding to the oxadiazolylphenylthiazole nucleus. The ${ }^{1} \mathrm{H}$ NMR spectra of the carboximidate-containing nucleophiles, compounds 24-28, showed two broad singlets peaks due to $\mathrm{NH}$ and $\mathrm{C}=\mathrm{NH}$ protons, in addition to the disappearance of the methylsulfonyl singlet peak at $3.47 \mathrm{ppm}$.

\subsection{Biological results and discussion}

2.2.1. Antibacterial activity. At the outset of this study, the initial antibacterial screening was performed on methicillinresistant Staphylococcus aureus (MRSA, 2658 RCMB). The results presented in Table 1 indicated that the 2-amino-1,3,4oxadiazole linker with aliphatic side chains (compounds 8-17) is void of anti-MRSA activity.

In contrast, the more polar side chains-morpholine, piperazine and hydroxyazetidine-provided the desired antibacterial activity, the maximum potency obtained from hydroxyazetidine-containing derivative 20, and inhibited the growth of MRSA at a minimum-inhibitory-concentration (MIC) of $3.1 \mu \mathrm{g} \mathrm{mL} \mathrm{m}^{-1}$ (one fold higher than the MIC of vancomycin against the same strain) (Table 1). Further expansion of the nitrogenous side chain provided the hydrazinyl and guanidinyl derivatives $\mathbf{2 1}$ and 22, both of which had a one-fold less potency than the parent compound 20. Derivatives with additional cyclic nitrogenous moieties (compounds 26-30) were found to be inactive or less active than the lead compound 20 (Table 1). 
Table 1 Initial MIC screening of the compounds against methicillinresistant Staphylococcus aureus (2658 RCMB)

\begin{tabular}{llll}
\hline & $\begin{array}{l}\text { MRSA (2658 } \\
\text { Compound }\end{array}$ & RCMB) & $\begin{array}{l}\text { MRSA (2658 } \\
\text { RCMB) }\end{array}$ \\
\hline $\mathbf{8}$ & 50 & $\mathbf{2 0}$ & 3.12 \\
$\mathbf{9}$ & $>50$ & $\mathbf{2 1}$ & 6.25 \\
$\mathbf{1 0}$ & $>50$ & $\mathbf{2 2}$ & 6.25 \\
$\mathbf{1 1}$ & $>50$ & $\mathbf{2 3}$ & 12.5 \\
$\mathbf{1 2}$ & $>50$ & $\mathbf{2 4}$ & 12.5 \\
$\mathbf{1 3}$ & $>50$ & $\mathbf{2 5}$ & 25 \\
$\mathbf{1 4}$ & $>50$ & $\mathbf{2 6}$ & 25 \\
$\mathbf{1 5}$ & $>50$ & $\mathbf{2 7}$ & 25 \\
$\mathbf{1 6}$ & $>50$ & $\mathbf{2 8}$ & $>50$ \\
$\mathbf{1 7}$ & $>50$ & $\mathbf{2 9}$ & $>50$ \\
$\mathbf{1 8}$ & 6.25 & $\mathbf{3 0}$ & $>50$ \\
$\mathbf{1 9}$ & 6.25 & Vancomycin & 1.56 \\
\end{tabular}

To further assess the antibacterial potency of this new class of arylthiazoles, the most promising derivative $\mathbf{2 0}$ was selected and its anti-staphylococcal activity was tested against twentyfour clinical isolates (Table 2).

Compound 20 exhibited moderate antibacterial activity against all methicillin-sensitive $S$. aureus (MSSA) and tested MRSA strains at concentrations ranging from 4 to $16 \mu \mathrm{g} \mathrm{mL}^{-1}$. Its $\mathrm{MBC}$ values were higher than $64 \mu \mathrm{g} \mathrm{mL} \mathrm{m}^{-1}$, more than threefold higher than its MIC values against the tested strains and evidence that the compound is a bacteriostatic agent. This mode of anti-staphylococcal inhibition was further confirmed using a time-killing assay at two different concentrations $(5 \times$

Table 2 The minimum inhibitory concentration ( $\mathrm{MIC}$ in $\mu \mathrm{g} \mathrm{mL}^{-1}$ ) and minimum bactericidal concentration ( $M B C$ in $\mu \mathrm{g} \mathrm{mL}^{-1}$ ) of compound 20 against a panel of Staphylococcus aureus clinically relevant strains

\begin{tabular}{|c|c|c|c|c|}
\hline \multirow[b]{2}{*}{ Bacterial strains } & \multicolumn{2}{|c|}{ Compound 20} & \multicolumn{2}{|c|}{ Vancomycin } \\
\hline & MIC & MBC & MIC & MBC \\
\hline MSSA ATCC 6538 & 4 & $>64$ & 1 & 2 \\
\hline MSSA NRS 107 & 4 & $>64$ & 2 & 2 \\
\hline MRSA NRS 108 & 4 & $>64$ & 1 & 2 \\
\hline MRSA NRS 194 & 8 & $>64$ & 1 & 1 \\
\hline MRSA NRS 119 & 8 & $>64$ & 1 & 1 \\
\hline MRSA NRS 382 (USA 100) & 16 & $>64$ & 2 & 2 \\
\hline MRSA NRS 383 (USA 200) & 8 & $>64$ & 1 & 1 \\
\hline MRSA NRS384 (USA 300) & 4 & $>64$ & 1 & 1 \\
\hline MRSA NRS123 (USA 400) & 8 & $>64$ & 1 & 1 \\
\hline MRSA NRS 385 (USA 500) & 4 & $>64$ & 0.5 & 1 \\
\hline MRSA NRS 386 (USA 700) & 8 & $>64$ & 1 & 1 \\
\hline MRSA NRS 387 (USA 800) & 4 & $>64$ & 0.5 & 0.5 \\
\hline MRSA NRS 483 (USA 1000) & 8 & $>64$ & 1 & 1 \\
\hline MRSA NRS 484 (USA 1100) & 8 & $>64$ & 2 & 2 \\
\hline VISA NRS 1 & 4 & $>64$ & 4 & 4 \\
\hline VISA NRS 19 & 8 & $>64$ & 4 & 4 \\
\hline VISA NRS 37 & 4 & $>64$ & 4 & 8 \\
\hline VRSA 2 & 4 & $>64$ & 64 & 64 \\
\hline VRSA 5 & 8 & $>64$ & $>64$ & $>64$ \\
\hline VRSA 6 & 8 & $>64$ & $>64$ & $>64$ \\
\hline VRSA 7 & 8 & $>64$ & $>64$ & $>64$ \\
\hline VRSA 9 & 8 & $>64$ & $>64$ & $>64$ \\
\hline VRSA 10 & 8 & $>64$ & 64 & $>64$ \\
\hline VRSA 11a & 8 & $>64$ & $>64$ & $>64$ \\
\hline
\end{tabular}
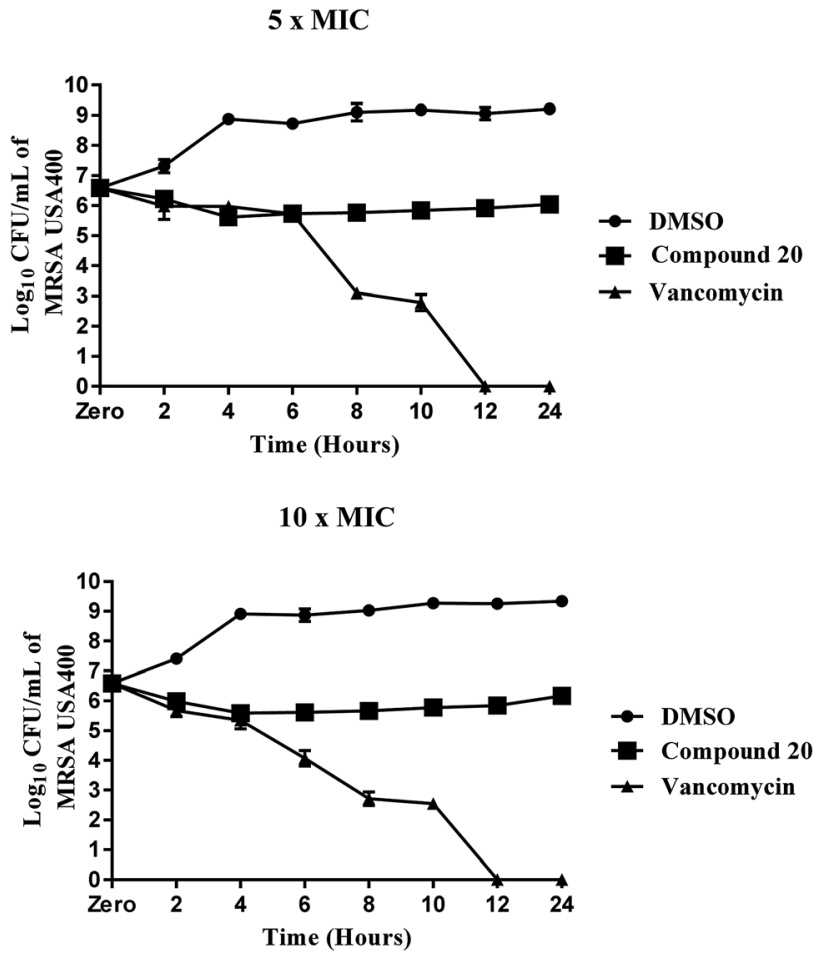

Fig. 2 Time-kill assay of compound 20 and vancomycin tested in triplicates (at $5 \times \mathrm{MIC}$ and $10 \times \mathrm{MIC}$ ) against methicillin-resistant Staphylococcus aureus (MRSA USA400) over a 24 hour incubation period at $37^{\circ} \mathrm{C}$. DMSO (solvent for the compound) served as a negative control. The error bars represent standard deviation values.

MIC and 10 $\times$ MIC) (Fig. 2). Despite a moderate potency against MRSA clinical isolates, compound 20 maintained its antibacterial potency against all nine-tested vancomycin-intermediate and vancomycin-resistant Staphylococcus aureus strains (VISA and VRSA). These findings suggest the advantages of this compound over vancomycin, the drug of choice for the treatment of invasive staphylococcal infections.

Similar to the results obtained with $S$. aureus strains, compound 20 exhibited moderate antibacterial activity against other clinically-important Gram-positive pathogens, and inhibited the growth of the tested strains at concentrations of 4 to $16 \mu \mathrm{g} \mathrm{mL}^{-1}$ (Table 3).

Most importantly, compound 20 also maintained its potency against vancomycin-resistant enterococci strains (i.e. vancomycin-resistant Enterococcus faecium and Enterococcus faecalis) (Table 3). Vancomycin-resistant enterococci (VRE) are a leading cause of healthcare-associated infections. VRE colonization can eventually lead to life-threatening endocarditis and urinary tract infections..$^{9-11}$ E. faecium is of high clinical interest and responsible for the vast majority of nosocomial enterococcal infections that result in patients with vancomycinresistant enterococcal endocarditis with limited therapeutic options. Moreover, the MBC values for compound 20 against the tested strains were more than threefold higher than its MIC values, evidence that compound $\mathbf{2 0}$ may be bacteriostatic against these strains. In addition, the preliminary safety profile of compound $\mathbf{2 0}$ was evaluated against two types of cell (vero 
Table 3 The minimum inhibitory concentration ( $\mathrm{MIC}$ in $\mu \mathrm{g} \mathrm{mL}^{-1}$ ) and minimum bactericidal concentration (MBC in $\mu \mathrm{g} \mathrm{mL}{ }^{-1}$ ) of compound 20 against a panel of Gram-positive bacterial pathogens

\begin{tabular}{|c|c|c|c|c|}
\hline Bacterial strains & MIC & MBC & MIC & MBC \\
\hline Enterococcus faecalis ATCC 51299 (VRE)1 & 16 & $>64$ & 32 & 64 \\
\hline Enterococcus faecium ATCC 700221 (VRE)1 & 8 & $>64$ & $>64$ & $>64$ \\
\hline Listeria monocytogenes ATCC 19111 & 8 & $>64$ & 1 & 1 \\
\hline
\end{tabular}

and caco-2 cells) and it showed high tolerability against both (Fig. 1S and $2 \mathrm{~S} \dagger$ ).

2.2.2. Antibiofilm activity. Given that approximately $65 \%$ of current human microbial infections are biofilms, ${ }^{12}$ it is predicted that biofilm will be the major source of future bacterial infections. Biofilm is a surmountable barrier to most of the antibiotic arsenal. Hence, common antibiotics such as penicillin and ciprofloxacin are losing their potency as a result of biofilm-induced infections. ${ }^{13}$ Staphylococci (in particular $S$. aureus and $S$. epidermidis) cause various biofilm-related infections. ${ }^{\mathbf{1 4}}$ They tend to form harmful biofilms on implanted prosthetic devices and tissues. ${ }^{15}$ Few antibacterial agents can disrupt these biofilms (MRSA biofilms in particular). Therefore, we evaluated the capacity of compound $\mathbf{2 0}$ to disrupt mature MRSA biofilm. Due to its large molecular structure and polar nature, vancomycin is unable to effectively penetrate such bacterial biofilms. At $1 \times$ MIC, vancomycin disrupted only about $8 \%$ of the MRSA biofilm (Fig. 3). This value increased to around $18 \%$ eradication of adherent biofilm when the concentration was doubled. Even at a concentration of $32 \times$ MIC, vancomycin was only capable of reducing the biofilm mass by $34 \%$ (data not published). Remarkably, the hydroxyzetidine derivative 20 was superior to vancomycin in MRSA biofilm eradication and

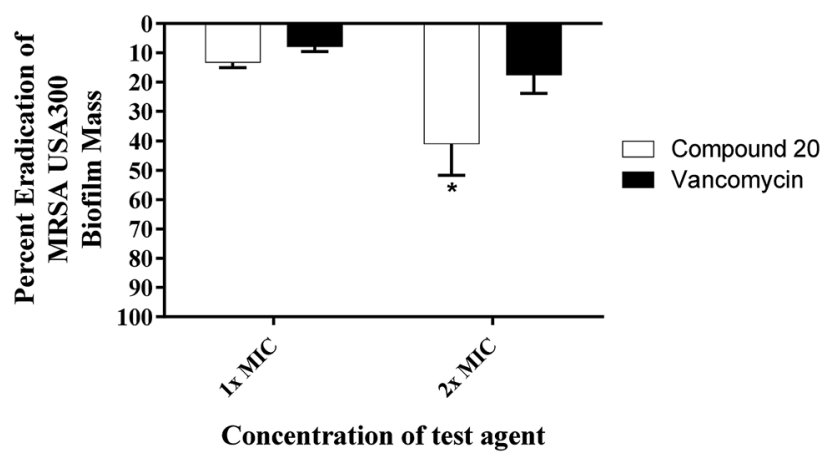

Fig. 3 Efficiency of compound 20 and vancomycin (tested in quartets) in disrupting the established MRSA biofilm. Data are presented as percent eradication of MRSA USA300 mature biofilm compared to the control (DMSO; the solvent for the tested compound). Error bars represent standard deviation values. Asterisk $(*)$ denotes statistical significance $(P<0.05)$ between results for compound 20 and vancomycin analyzed via one-way ANOVA with post hoc Dennett's test for multiple comparisons.

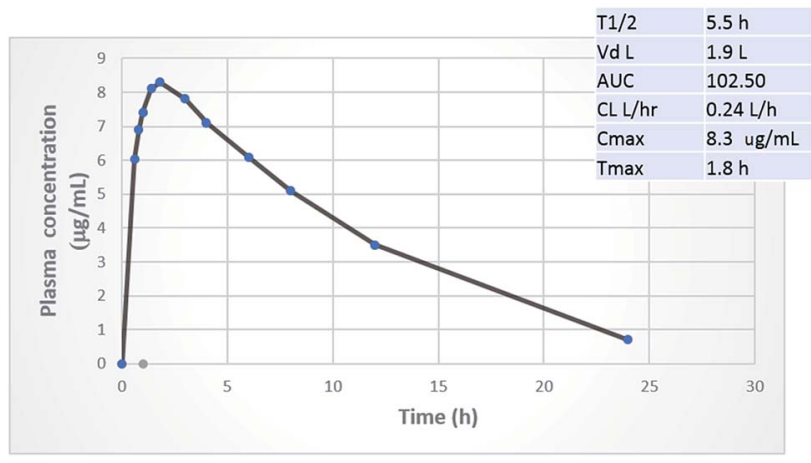

Fig. 4 Oral pharmacokinetic curve and key PK parameters in the rat after $25 \mathrm{mg} \mathrm{kg}^{-1}$ oral dose of compound 20 .

exhibited a concentration-dependent biofilm disruption (Fig. 3). At $1 \times$ MIC, compound 20 disrupted $13 \%$ of the mature MRSA300 biofilm mass. This increased to about $41 \%$ eradication of the adherent biofilm when its concentration was increased by one-fold ( $2 \times$ MIC) (Fig. 3$)$.

2.2.3. In vivo pharmacokinetic evaluation. The principal challenge of designing an orally administered antibiotic is that its plasma concentration has to exceed its MIC values. So far, most of the newly-introduced antibiotics, such as ceftaroline ${ }^{\mathbf{1 6}}$ and lipoglycopeptides are taken parenterally. ${ }^{17}$ When phenylthiazoles were first discovered, their main drawback was the extremely short plasma half-life of the early generation, for which the $t_{1 / 2}$ of the lead compound 1 (Fig. 1) was only 29 minutes. ${ }^{2}$ To assess whether the chemical modifications presented in this study have the expected positive impact on the pharmacokinetic profile, a rat was administered a $25 \mathrm{mg} \mathrm{kg}^{-1}$ oral dosage of compound 20. Fig. 4 indicates that compound 20 possesses high metabolic stability with a biological half-life of 5.5 hours and low clearance rate. Most importantly, compound 20 reaches a plasma concentration that surpasses its MIC values against most of the tested multidrug-resistant clinical isolates.

\section{Conclusions}

Building a hybrid scaffold with the $t$-butylphenyl lipophilic part and oxadiazole linker followed by a study of the proper 
nitrogenous substituent at oxadiazole position-5 provided compound 20 with 3-hydroxyazetidine moiety as the most promising derivative. Interestingly, the unsubstituted azetidinyl analogue 15 was void of any antibacterial activity. The moderate antibacterial potency of hydroxyazetidinyl derivative 20, when tested against around thirty Gram-positive multidrug-resistant strains, was advantageous over vancomycin, the drug of choice for the treatment of invasive, life-threatening staphylococcal infections, and effective against all tested vancomycinresistant species (i.e. VRSA and VRE). Furthermore, it was highly tolerable on vero cells and caco-2 cells. Moreover, compound 20 was more than two-fold better than vancomycin in its ability to disrupt bacterial biofilm mass. Another advantage of compound $\mathbf{2 0}$ over vancomycin and other phenylthiazoles is its highly acceptable pharmacokinetic profile: a biological half-life that is 11-fold more than the lead compound 1a with oral absorbability.

\section{Experimental}

\subsection{General}

${ }^{1} \mathrm{H}$ NMR spectra were run at $400 \mathrm{MHz}$ and ${ }^{13} \mathrm{C}$ NMR spectra were determined at $100 \mathrm{MHz}$ in deuterated chloroform $\left(\mathrm{CDCl}_{3}\right)$, or dimethyl sulfoxide (DMSO- $d_{6}$ ) on a Varian Mercury VX-400 NMR spectrometer. Chemical shifts are given in parts per million (ppm) on the delta $(\delta)$ scale. Chemical shifts were calibrated relative to those of the solvents. Flash chromatography was performed on 230-400 mesh silica. The progress of reactions was monitored with Merck silica gel IB2-F plates ( $0.25 \mathrm{~mm}$ thickness). The infrared spectra were recorded in potassium bromide disks on pye Unicam SP 3300 and Shimadzu FT IR 8101 PC infrared spectrophotometer. Mass spectra were recorded at $70 \mathrm{eV}$. Highresolution mass spectra for all ionization techniques were obtained from a FinniganMAT XL95. Melting points were determined using capillary tubes with a Stuart SMP30 apparatus and are uncorrected. All yields reported referring to isolated yields.

4.1.1. Ethyl 2-(4-(tert-Butyl)phenyl)-4-methylthiazole-5carboxylate (3). Compound $2(3 \mathrm{~g}, 14 \mathrm{mmol})$ and ethyl 2chloro-3-oxobutanoate $(3.88 \mathrm{~mL}, 4.62 \mathrm{~g}, 28 \mathrm{mmol})$ were added to absolute ethanol $(30 \mathrm{~mL})$. The reaction mixture was heated at reflux for $4 \mathrm{~h}$. After removal of solvent under reduced pressure, the solid residue was purified by crystallization from ethanol to provide the desired product as white crystals $(4.4 \mathrm{~g}, 95 \%) \mathrm{mp}=$ $105{ }^{\circ} \mathrm{C} ;{ }^{1} \mathrm{H}$ NMR (DMSO- $\left.d_{6}\right) \delta: 7.79(\mathrm{~d}, J=8.4 \mathrm{~Hz}, 2 \mathrm{H}), 7.49(\mathrm{~d}, J$ $=8.4 \mathrm{~Hz}, 2 \mathrm{H}), 4.33(\mathrm{q}, J=4.8 \mathrm{~Hz}, 2 \mathrm{H}), 2.67(\mathrm{~s}, 3 \mathrm{H}), 1.29(\mathrm{~s}, 9 \mathrm{H})$, $1.13(\mathrm{t}, J=4.8 \mathrm{~Hz}, 3 \mathrm{H}) ;{ }^{13} \mathrm{C}$ NMR (DMSO- $\left.d_{6}\right) \delta: 169.1,154.5$, 153.8, 139.5, 130.8, 126.7, 126.1, 115.3, 61.8, 35.1, 28.8, 17.7, 14.5; MS $(\mathrm{m} / \mathrm{z}) 303$; anal. calc. for: $\left(\mathrm{C}_{17} \mathrm{H}_{21} \mathrm{NO}_{2} \mathrm{~S}\right): \mathrm{C}, 67.30 ; \mathrm{H}$, 6.98; N, 4.62\%; found: C, 67.32; H, 6.99; N, 4.63\%.

\subsubsection{2-(4-(tert-Butyl)phenyl)-4-methylthiazole-5-}

carbohydrazide (4). To a solution of $3(1.29 \mathrm{~g}, 4 \mathrm{mmol})$ in ethanol (15 mL), hydrazine hydrate $(99 \%, 1 \mathrm{~mL}, 20 \mathrm{mmol})$ was added dropwise. The reaction mixture was heated at reflux for $8 \mathrm{~h}$ then allowed to cool down to room temperature. The formed solid was separated by filtration and crystallized from ethanol to provide the desired product as white crystals $(1.1 \mathrm{~g}, 93 \%) \mathrm{mp}=$ 204-205 ${ }^{\circ} \mathrm{C} ;{ }^{1} \mathrm{H}$ NMR (DMSO- $d_{6}$ ) $\delta: 9.57$ (brs, $1 \mathrm{H}$ ), 7.82 (d, $J=$
$8.4 \mathrm{~Hz}, 2 \mathrm{H}), 7.49$ (d, $J=8.4 \mathrm{~Hz}, 2 \mathrm{H}), 4.54$ (brs, 2H), 2.65 (s, 3H), 1.30SS (s, 9H); ${ }^{13} \mathrm{C}$ NMR (DMSO- $d_{6}$ ) $\delta: 165.6,155.2,153.5,142.3$, 130.9, 126.7, 126.4, 115.3, 35.1, 18.7, 17.3; MS (m/z) 289; anal. calc. for: $\left(\mathrm{C}_{15} \mathrm{H}_{19} \mathrm{~N}_{3} \mathrm{OS}\right): \mathrm{C}, 62.26 ; \mathrm{H}, 6.62 ; \mathrm{N}, 14.52 \%$; found: $\mathrm{C}$, 62.27 ; H, 6.63; N, 14.53\%.

4.1.3. 2-(2-(4-(tert-Butyl)phenyl)-4-methylthiazol-5-yl)-5(methylthio)-1,3,4-oxadiazole (6). Potassium hydroxide $(0.4 \mathrm{~g}$, $10 \mathrm{mmol})$ was added to a solution of $4(3 \mathrm{~g}, 10 \mathrm{mmol})$ in ethanol $(15 \mathrm{~mL})$, followed by drop-wise addition of carbon disulphide (3 $\mathrm{mL}, 110 \mathrm{mmol}$ ) over $0.5 \mathrm{~h}$. The reaction mixture was stirred at room temperature for an additional $15 \mathrm{~min}$ and then heated to reflux until the evolution of hydrogen sulfide gas ceased. After completion of the reaction, as monitored by TLC, the obtained intermediate was poured on cold water $(50 \mathrm{~mL})$, filtered, washed with water, dried and crystallized from ethanol to provide potassium salt 5 as yellow crystals $(3.4 \mathrm{~g}, 89 \%) \mathrm{mp}>300{ }^{\circ} \mathrm{C} ;{ }^{1} \mathrm{H}$ NMR (DMSO- $\left.d_{6}\right) \delta: 7.89(\mathrm{~d}, J=8.4 \mathrm{~Hz}, 2 \mathrm{H}), 7.53(\mathrm{~d}, J=8.4 \mathrm{~Hz}$, $2 \mathrm{H}), 2.64(\mathrm{~s}, 3 \mathrm{H}), 1.29(\mathrm{~s}, 9 \mathrm{H}) ;{ }^{13} \mathrm{C}$ NMR (DMSO- $\left.d_{6}\right) \delta: 167.6$, 159.4, 158.1, 155.1, 154.3, 130.2, 126.6, 126.5, 111.7, 35.1, 31.3, 18.7; MS $(\mathrm{m} / \mathrm{z}) 369$. The obtained salt 5 (0.8 g, $2.1 \mathrm{mmol})$ was dissolved in water $(15 \mathrm{~mL})$. Then, dimethyl sulfate $(0.5 \mathrm{~mL}, 4$ $\mathrm{mmol}$ ) was added dropwise with vigorous stirring. After $2 \mathrm{~h}$, the formed solid was filtered and washed with copious amounts of water to yield the titled compound 6 as a yellowish white solid $(0.68 \mathrm{~g}, 91 \%) ; \mathrm{mp}=173{ }^{\circ} \mathrm{C} ;{ }^{1} \mathrm{H}$ NMR $\left(\mathrm{DMSO}-d_{6}\right) \delta: 7.93(\mathrm{~d}, J=$ $8.4 \mathrm{~Hz}, 2 \mathrm{H}), 7.56$ (d, $J=8.4 \mathrm{~Hz}, 2 \mathrm{H}), 2.77$ (s, 3H), $2.68(\mathrm{~s}, 3 \mathrm{H})$, $1.31(\mathrm{~s}, 9 \mathrm{H}) ;{ }^{13} \mathrm{C}$ NMR (DMSO- $\left.d_{6}\right) \delta: 166.5,162.5,159.4,153.9$, 153.4, 130.5, 126.5, 126.4, 106.5, 39.3, 35.1, 28.2, 18.6; MS (m/z) 345 ; anal. calc. for: $\left(\mathrm{C}_{17} \mathrm{H}_{19} \mathrm{~N}_{3} \mathrm{OS}_{2}\right)$ : C, 59.10; $\mathrm{H}, 5.54 ; \mathrm{N}, 12.16 \%$; found: $\mathrm{C}, 59.12 ; \mathrm{H}, 5.55 ; \mathrm{N}, 12.17 \%$.

4.1.4. 2-(2-(4-(tert-Butyl)phenyl)-4-methylthiazol-5-yl)-5(methylsulfonyl)-1,3,4-oxadiazole (7). To a solution of 6 (0.5 g, $1.3 \mathrm{mmol})$ in dry DCM (5 mL), $m$-CPBA (0.514 g, $2.9 \mathrm{mmol})$ diluted with DCM (5 mL) was added portion-wise with continuous stirring. Afterward, the reaction mixture was kept at $23{ }^{\circ} \mathrm{C}$ for $16 \mathrm{~h}$, additional DCM $(10 \mathrm{~mL})$ was added and the reaction mixture was washed with $25 \mathrm{~mL}$ of $5 \%$ aqueous solution of sodium metabisulfite, and $25 \mathrm{~mL}$ of $5 \%$ aqueous sodium carbonate. The organic layer was separated, dried and concentrated under reduced pressure to give the desired product as yellow crystals $(0.5 \mathrm{~g}, 93 \%) \mathrm{mp}=144{ }^{\circ} \mathrm{C} ;{ }^{1} \mathrm{H}$ NMR (DMSO- $\left.d_{6}\right) \delta$ : $7.88(\mathrm{~d}, J=8.4 \mathrm{~Hz}, 2 \mathrm{H}), 7.50(\mathrm{~d}, J=8.4 \mathrm{~Hz}, 2 \mathrm{H}), 3.47(\mathrm{~s}, 3 \mathrm{H}), 2.76$ $(\mathrm{s}, 3 \mathrm{H}), 1.29$ (s, 9H); ${ }^{13} \mathrm{C}$ NMR (DMSO- $\left.d_{6}\right) \delta: 165.3,159.2,159.0$, 158.3, 157.0, 130.1, 126.7, 126.6, 118.4, 42.2, 35.1, 31.2, 18.9; MS $(m / z) 377$; anal. calc. for: $\left(\mathrm{C}_{17} \mathrm{H}_{19} \mathrm{~N}_{3} \mathrm{O}_{3} \mathrm{~S}_{2}\right)$ : C, 54.09; $\mathrm{H}, 5.07 ; \mathrm{N}$, $11.13 \%$; found: $\mathrm{C}, 54.11 ; \mathrm{H}, 5.08 ; \mathrm{N}, 11.15 \%$.

\subsection{Compounds 8-30}

4.2.1. General procedure. To a solution of $7(0.1 \mathrm{~g}, 0.25$ $\mathrm{mmol}$ ) in dry DMF (5 mL), appropriate amine, hydrazine, guanidine or carboximidate $(0.4 \mathrm{mmol})$; namely: methylamine, ethylamine, butylamine, isopropylamine, cyclopentylamine, cyclohexylamine, dimethylamine, azetidine hydrochloride, pyrrolidine, piperidine, morpholine, 4-methylpiperazine, azetidin-3-ol hydrochloride, hydrazine hydrate, guanidine hydrochloride, methylguanidine hydrochloride, 1,1- 
dimethylguanidine hydrochloride, $N, N$-tetramethyl guanidine, morpholine-4-carboximidamide hydroiodide, 4methylpiperazine-1-carboximidamide hydroiodide, picolinimidamide hydrochloride, nicotinimidamide hydrochloride, isonicotinimidamide hydrochloride, was added. The reaction mixture was heated at $80{ }^{\circ} \mathrm{C}$ for $0.5-12 \mathrm{~h}$ and then poured over ice water $(50 \mathrm{~mL})$. The formed solid was extracted with ethyl acetate $(10 \mathrm{~mL})$. The organic layer was evaporated under reduced pressure. The obtained crude material was then purified by crystallization or column chromatography. Physical properties and spectral analysis of isolated products are listed below:

\subsubsection{5-(2-(4-(tert-Butyl)phenyl)-4-methylthiazol-5-yl)- $\mathrm{N}$ -} methyl-1,3,4-oxadiazol-2-amine (8). Following the general procedure 4.2.1., and using methylamine (13 $\mu \mathrm{L}, 0.4 \mathrm{mmol})$, compound 8 was obtained as yellow solid $(0.08 \mathrm{~g}, 88 \%) \mathrm{mp}=$ $223{ }^{\circ} \mathrm{C} ;{ }^{1} \mathrm{H}$ NMR (DMSO- $\left.d_{6}\right) \delta: 7.85$ (d, $J=8.4 \mathrm{~Hz}, 2 \mathrm{H}$ ), 7.77 (brs, $1 \mathrm{H}), 7.51(\mathrm{~d}, J=8.4 \mathrm{~Hz}, 2 \mathrm{H}), 2.87(\mathrm{~s}, 3 \mathrm{H}), 2.61(\mathrm{~s}, 3 \mathrm{H}), 1.30(\mathrm{~s}$, $9 \mathrm{H}) ;{ }^{13} \mathrm{C}$ NMR (DMSO- $d_{6}$ ) $\delta: 166.1,164.2,154.3,154.1,153.8$, 130.0, 126.5, 126.5, 115.0, 35.1, 29.5, 26.8, 17.3; MS $(\mathrm{m} / \mathrm{z}) 328$; HRMS (EI) $m / z 328.1358 \mathrm{M}^{+}$, calcd for $\mathrm{C}_{17} \mathrm{H}_{20} \mathrm{~N}_{4} \mathrm{OS} 328.1358$; anal. calc. for: $\left(\mathrm{C}_{17} \mathrm{H}_{20} \mathrm{~N}_{4} \mathrm{OS}\right)$ : C, 62.17; $\mathrm{H}, 6.14 ; \mathrm{N}, 17.06 \%$; found: $\mathrm{C}, 62.18 ; \mathrm{H}, 6.15 ; \mathrm{N}, 17.07 \%$.

4.2.3. 5-(2-(4-(tert-Butyl)phenyl)-4-methylthiazol-5-yl)- $N$ ethyl-1,3,4-oxadiazol-2-amine (9). Following the general procedure 4.2.1., and using ethylamine ( $18 \mu \mathrm{L}, 0.4 \mathrm{mmol})$, compound 9 was obtained as yellow solid $(0.05 \mathrm{~g}, 55 \%) \mathrm{mp}=200{ }^{\circ} \mathrm{C} ;{ }^{1} \mathrm{H}$ NMR (DMSO- $\left.d_{6}\right) \delta: 8.26$ (brs, 1H),7.90 (d, $\left.J=8.4 \mathrm{~Hz}, 2 \mathrm{H}\right), 7.54(\mathrm{~d}$, $J=8.4 \mathrm{~Hz}, 2 \mathrm{H}), 3.21(\mathrm{~m}, 2 \mathrm{H}), 2.68$ (s, 3H), 1.37 (s, 9H), 1.14 (m, $3 \mathrm{H}) ;{ }^{13} \mathrm{C}$ NMR (DMSO- $d_{6}$ ) $\delta: 166.0,163.5,154.3,154.1,153.7$, 130.0, 126.8, 126.6, 115.0, 37.9, 34.6, 31.3, 17.4, 15.17; MS (m/z) 342; HRMS (EI) $m / z \quad 342.1514 \mathrm{M}^{+}$, calcd for $\mathrm{C}_{18} \mathrm{H}_{22} \mathrm{~N}_{4} \mathrm{OS}$ 342.1514; anal. calc. for: $\left(\mathrm{C}_{18} \mathrm{H}_{22} \mathrm{~N}_{4} \mathrm{OS}\right): \mathrm{C}, 63.13 ; \mathrm{H}, 6.48 ; \mathrm{N}$, $16.36 \%$; found: $\mathrm{C}, 63.15 ; \mathrm{H}, 6.50 ; \mathrm{N}, 16.37 \%$.

4.2.4. $\quad N$-Butyl-5-(2-(4-(tert-butyl)phenyl)-4-methylthiazol-5yl)-1,3,4-oxadiazol-2-amine (10). Following the general procedure 4.2.1., and using ethylamine ( $29 \mu \mathrm{L}, 0.4 \mathrm{mmol})$, compound 10 was obtained as yellow solid $(0.09 \mathrm{~g}, 93 \%) \mathrm{mp}=145{ }^{\circ} \mathrm{C} ;{ }^{1} \mathrm{H}$ NMR (DMSO- $d_{6}$ ) $\delta: 7.88$ (d, $\left.J=8.4 \mathrm{~Hz}, 2 \mathrm{H}\right), 7.83$ (brs, 1H), 7.53 $(\mathrm{d}, J=8.4 \mathrm{~Hz}, 2 \mathrm{H}), 3.37(\mathrm{t}, J=3.2 \mathrm{~Hz}, 2 \mathrm{H}), 2.66(\mathrm{~s}, 3 \mathrm{H}), 1.94(\mathrm{~m}$, $2 \mathrm{H}), 1.70(\mathrm{~m}, 2 \mathrm{H}), 1.54(\mathrm{~m}, 3 \mathrm{H}), 1.29(\mathrm{~s}, 9 \mathrm{H}) ;{ }^{13} \mathrm{C}$ NMR (DMSO- $\left.d_{6}\right)$ $\delta: 166.4,162.9,154.3,153.7,152.7,130.0,126.6,126.5,128.6$, 127.9, 127.3, 127.1, 115.4, 42.7, 31.2, 19.8, 17.4, 14.0; MS (m/z) 370 ; HRMS (EI) $m / z \quad 370.1827 \mathrm{M}^{+}$, calcd for $\mathrm{C}_{20} \mathrm{H}_{26} \mathrm{~N}_{4} \mathrm{OS}$ 370.1827; anal. calc. for: $\left(\mathrm{C}_{20} \mathrm{H}_{26} \mathrm{~N}_{4} \mathrm{OS}\right): \mathrm{C}, 64.83 ; \mathrm{H}, 7.07 ; \mathrm{N}$, $15.12 \%$; found: C, 64.84; H, 7.09; N, 15.13\%

4.2.5. 5-(2-(4-(tert-Butyl)phenyl)-4-methylthiazol-5-yl)- $N$ isopropyl-1,3,4-oxadiazol-2-amine (11). Following the general procedure 4.2.1., and using ethylamine (23 $\mu \mathrm{L}, 0.4 \mathrm{mmol})$, compound 11 was obtained as yellow solid $(0.06 \mathrm{~g}, 81 \%) \mathrm{mp}=$ $220{ }^{\circ} \mathrm{C} ;{ }^{1} \mathrm{H}$ NMR (DMSO- $\left.d_{6}\right) \delta: 7.88(\mathrm{~d}, J=8.4 \mathrm{~Hz}, 2 \mathrm{H}), 7.82$ (brs, $1 \mathrm{H}), 7.53(\mathrm{~d}, J=8.4 \mathrm{~Hz}, 2 \mathrm{H}), 3.70(\mathrm{~m}, 1 \mathrm{H}), 2.65(\mathrm{~s}, 3 \mathrm{H}), 1.29(\mathrm{~s}$, 9H), $1.20(\mathrm{~d}, J=6.8 \mathrm{~Hz}, 6 \mathrm{H}) ;{ }^{13} \mathrm{C}$ NMR (DMSO- $\left.d_{6}\right) \delta: 166.5,162.9$, 154.3, 153.7, 152.8, 130.0, 126.6, 126.6, 115.0, 45.4, 35.1, 31.3, 22.7, 17.3; MS (m/z) 356; HRMS (EI) $m / z 356.1671 \mathrm{M}^{+}$, calcd for $\mathrm{C}_{19} \mathrm{H}_{24} \mathrm{~N}_{4} \mathrm{OS} 356.1671$; anal. calc. for: $\left(\mathrm{C}_{19} \mathrm{H}_{24} \mathrm{~N}_{4} \mathrm{OS}\right)$ : C, 64.02; $\mathrm{H}$, 6.79 ; N, 15.72\%; found: C, 64.02; H, 6.80; N, 15.73\%.
4.2.6. 5-(2-(4-(tert-Butyl)phenyl)-4-methylthiazol-5-yl)- $\mathrm{N}$ cyclopentyl-1,3,4-oxadiazol-2-amine (12). Following the general procedure 4.2.1., and using cyclopentylamine ( $34 \mu \mathrm{L}, 0.4 \mathrm{mmol})$, compound 12 was obtained as yellow solid $(0.06 \mathrm{~g}, 60 \%) \mathrm{mp}=$ $195{ }^{\circ} \mathrm{C} ;{ }^{1} \mathrm{H}$ NMR (DMSO- $\left.d_{6}\right) \delta: 7.95$ (brs, $\left.1 \mathrm{H}\right), 7.86(\mathrm{~d}, J=8.4 \mathrm{~Hz}$, $2 \mathrm{H}), 7.51$ (d, $J=8.4 \mathrm{~Hz}, 2 \mathrm{H}), 3.87(\mathrm{~m}, 1 \mathrm{H}), 2.65$ (s, 3H), $1.91(\mathrm{~m}$, $2 \mathrm{H}), 1.65(\mathrm{~m}, 2 \mathrm{H}), 1.58(\mathrm{~m}, 4 \mathrm{H}), 1.28(\mathrm{~s}, 9 \mathrm{H}) ;{ }^{13} \mathrm{C}$ NMR (DMSO- $\left.d_{6}\right)$ $\delta: 166.4,163.2$, 154.3, 153.7, 152.8, 130.0, 126.6, 126.5, 115.0, 54.8, 35.1, 32.6, 31.2, 23.6, 17.3; MS ( $\mathrm{m} / \mathrm{z}$ ) 382; HRMS (EI) $\mathrm{m} / \mathrm{z}$ 382.1827 $\mathrm{M}^{+}$, calcd for $\mathrm{C}_{21} \mathrm{H}_{26} \mathrm{~N}_{4} \mathrm{OS} 382.1827$; anal. calc. for: $\left(\mathrm{C}_{21} \mathrm{H}_{26} \mathrm{~N}_{4} \mathrm{OS}\right): \mathrm{C}, 65.94 ; \mathrm{H}, 6.85 ; \mathrm{N}, 14.65 \%$; found: $\mathrm{C}, 65.96 ; \mathrm{H}$, $6.86 ; \mathrm{N}, 14.67 \%$.

4.2.7. 5-(2-(4-(tert-Butyl)phenyl)-4-methylthiazol-5-yl)- $N$ cyclohexyl-1,3,4-oxadiazol-2-amine (13). Following the general procedure 4.2.1., and using cyclohexylamine ( $39 \mu \mathrm{L}, 0.4 \mathrm{mmol})$, compound 13 was obtained as light brown solid $(0.08 \mathrm{~g}, 76 \%)$ $\mathrm{mp}=186{ }^{\circ} \mathrm{C} ;{ }^{1} \mathrm{H}$ NMR (DMSO- $\left.d_{6}\right) \delta: 7.95$ (brs, $\left.1 \mathrm{H}\right), 7.88(\mathrm{~d}, J=$ $8.4 \mathrm{~Hz}, 2 \mathrm{H}), 7.53(\mathrm{~d}, J=8.4 \mathrm{~Hz}, 2 \mathrm{H}), 3.22(\mathrm{~m}, 1 \mathrm{H}), 2.65(\mathrm{~s}, 3 \mathrm{H})$, $1.54(\mathrm{~m}, 4 \mathrm{H}), 1.32(\mathrm{~m}, 4 \mathrm{H}), 1.29(\mathrm{~s}, 2 \mathrm{H}), 0.90(\mathrm{~m}, 2 \mathrm{H}) ;{ }^{13} \mathrm{C} \mathrm{NMR}$ $\left(\mathrm{DMSO}-d_{6}\right) \delta$ : 166.5, 163.6, 154.3, 153.7, 152.8, 130.0, 126.6, 126.5, 115.0, 42.7, 35.1, 31.3, 31.2, 19.8, 17.3, 14.0; MS (m/z) 396; HRMS (EI) $m / z$ 396.1984 $\mathrm{M}^{+}$, calcd for $\mathrm{C}_{22} \mathrm{H}_{28} \mathrm{~N}_{4} \mathrm{OS} 396.1984$; anal. calc. for: $\left(\mathrm{C}_{22} \mathrm{H}_{28} \mathrm{~N}_{4} \mathrm{OS}\right): \mathrm{C}, 66.63 ; \mathrm{H}, 7.12 ; \mathrm{N}, 14.13 \%$; found: C, 66.64; H, 7.13; N, 14.14\%.

4.2.8. 5-(2-(4-(tert-Butyl)phenyl)-4-methylthiazol-5-yl)- $N, N$ dimethyl-1,3,4-oxadiazol-2-amine (14). Following the general procedure 4.2.1., and using dimethylamine (18 $\mu \mathrm{L}, 0.4 \mathrm{mmol})$, compound 14 was obtained as yellow solid (0.07 g, 80\%) $\mathrm{mp}=$ $185{ }^{\circ} \mathrm{C} ;{ }^{1} \mathrm{H}$ NMR (DMSO- $\left.d_{6}\right) \delta: 7.89(\mathrm{~d}, J=8.4 \mathrm{~Hz}, 2 \mathrm{H}), 7.53(\mathrm{~d}, J=$ $8.4 \mathrm{~Hz}, 2 \mathrm{H}), 3.04(\mathrm{~s}, 6 \mathrm{H}), 2.66(\mathrm{~s}, 3 \mathrm{H}), 1.29$ (s, 9H); ${ }^{13} \mathrm{C}$ NMR (DMSO$\left.d_{6}\right) \delta: 166.6,164.6,154.4,153.9,153.5,130.0,126.6,126.6,114.9$, 38.1, 35.1, 31.3, 17.3; MS (m/z) 342; HRMS (EI) $m / z 342.1514 \mathrm{M}^{+}$, calcd for $\mathrm{C}_{18} \mathrm{H}_{22} \mathrm{~N}_{4} \mathrm{OS} 342.1514$; anal. calc. for: $\left(\mathrm{C}_{18} \mathrm{H}_{22} \mathrm{~N}_{4} \mathrm{OS}\right): \mathrm{C}$, 63.13; H, 6.48; N, 16.36\%; found: C, 63.14; H, 6.50; N, 16.37\%.

4.2.9. 2-(Azetidin-1-yl)-5-(2-(4-(tert-butyl)phenyl)-4methylthiazol-5-yl)-1,3,4-oxadiazole (15). Following the general procedure 4.2.1., and using azetidine hydrochloride $(0.04 \mathrm{~g}, 0.4$ $\mathrm{mmol})$, compound 15 was obtained as yellow solid $(0.07 \mathrm{~g}, 70 \%)$ $\mathrm{mp}=228{ }^{\circ} \mathrm{C} ;{ }^{1} \mathrm{H}$ NMR (DMSO- $\left.d_{6}\right) \delta: 7.89(\mathrm{~d}, J=8.4 \mathrm{~Hz}, 2 \mathrm{H}), 7.52$ $(\mathrm{d}, J=8.4 \mathrm{~Hz}, 2 \mathrm{H}), 4.14(\mathrm{t}, J=8 \mathrm{~Hz}, 4 \mathrm{H}), 2.87(\mathrm{~m}, 2 \mathrm{H}), 2.69(\mathrm{~s}$, $3 \mathrm{H}), 1.28$ (s, 9H); ${ }^{13} \mathrm{C}$ NMR (DMSO- $\left.d_{6}\right) \delta: 166.9,164.7,162.7$, 154.4, 154.3, 129.9, 126.6, 126.5, 114.6, 52.5, 35.1, 31.2, 17.8, 17.3; MS (m/z) 354; HRMS (EI) $m / z 354.1514 \mathrm{M}^{+}$, calcd for $\mathrm{C}_{19} \mathrm{H}_{22} \mathrm{~N}_{4} \mathrm{OS} \mathrm{354.1514;} \mathrm{anal.} \mathrm{calc.} \mathrm{for:}\left(\mathrm{C}_{19} \mathrm{H}_{22} \mathrm{~N}_{4} \mathrm{OS}\right): \mathrm{C}, 64.38 ; \mathrm{H}$, 6.26 ; N, 15.81\%; found: C, 64.40; H, 6.27; N, 15.83\%.

4.2.10. 2-(2-(4-(tert-Butyl)phenyl)-4-methylthiazol-5-yl)-5(pyrrolidin-1-yl)-1,3,4-oxadiazole (16). Following the general procedure 4.2.1., and using pyrrolidine (28 $\mu \mathrm{L}, 0.4 \mathrm{mmol})$, compound 16 was obtained as yellow solid $(0.089 \mathrm{~g}, 91 \%) \mathrm{mp}=$ $226{ }^{\circ} \mathrm{C} ;{ }^{1} \mathrm{H}$ NMR (DMSO- $\left.d_{6}\right) \delta: 7.89(\mathrm{~d}, J=8.4 \mathrm{~Hz}, 2 \mathrm{H}), 7.53(\mathrm{~d}, J$ $=8.4 \mathrm{~Hz}, 2 \mathrm{H}), 3.48(\mathrm{~m}, 4 \mathrm{H}), 2.65(\mathrm{~s}, 3 \mathrm{H}), 1.96(\mathrm{~m}, 4 \mathrm{H}), 1.27(\mathrm{~s}$, $9 \mathrm{H}) ;{ }^{13} \mathrm{C}$ NMR (DMSO- $\left.d_{6}\right) \delta: 166.5,162.4,154.4,153.8,153.2$, 130.0, 126.63, 126.61, 114.2 , 48.0, 35.1, 31.3, 25.5, 17.3; MS (m/z) 368; HRMS (EI) $m / z 368.1671 \mathrm{M}^{+}$, calcd for $\mathrm{C}_{20} \mathrm{H}_{24} \mathrm{~N}_{4} \mathrm{OS}$ 368.1671; anal. calc. for: $\left(\mathrm{C}_{20} \mathrm{H}_{24} \mathrm{~N}_{4} \mathrm{OS}\right): \mathrm{C}, 65.19 ; \mathrm{H}, 6.57$; , $15.20 \%$; found: $\mathrm{C}, 65.20 ; \mathrm{H}, 6.58 ; \mathrm{N}, 15.21 \%$ 
4.2.11. 2-(2-(4-(tert-Butyl)phenyl)-4-methylthiazol-5-yl)-5(piperidin-1-yl)-1,3,4-oxadiazole (17). Following the general procedure 4.2.1., and using piperidine $(34 \mu \mathrm{L}, 0.4 \mathrm{mmol})$, compound 17 was obtained as yellow solid $(0.098 \mathrm{~g}, 97 \%) \mathrm{mp}=$ $285{ }^{\circ} \mathrm{C} ;{ }^{1} \mathrm{H}$ NMR (DMSO- $\left.d_{6}\right) \delta: 7.89(\mathrm{~d}, J=8.4 \mathrm{~Hz}, 2 \mathrm{H}), 7.54(\mathrm{~d}, J$ $=8.4 \mathrm{~Hz}, 2 \mathrm{H}), 3.45(\mathrm{~m}, 4 \mathrm{H}), 2.66(\mathrm{~s}, 3 \mathrm{H}), 1.59(\mathrm{~m}, 6 \mathrm{H}), 1.29(\mathrm{~s}$, $9 \mathrm{H}) ;{ }^{13} \mathrm{C}$ NMR (DMSO- $\left.d_{6}\right) \delta: 166.7,164.0,154.4,154.0,153.5$, 130.0, 126.64, 126.63, 114.8, 47.1, 35.1, 31.3, 24.8, 23.6, 17.4; MS $\left(\mathrm{m} / \mathrm{z}\right.$ ) 382; HRMS (EI) $m / z 382.1827 \mathbf{M}^{+}$, calcd for $\mathrm{C}_{21} \mathrm{H}_{26} \mathrm{~N}_{4} \mathrm{OS}$ 382.1827; anal. calc. for: $\left(\mathrm{C}_{21} \mathrm{H}_{26} \mathrm{~N}_{4} \mathrm{OS}\right): \mathrm{C}, 65.94 ; \mathrm{H}, 6.85 ; \mathrm{N}$, $14.65 \%$; found: $\mathrm{C}, 65.95 ; \mathrm{H}, 6.87$; N, 14.67\%.

4.2.12. 4-(5-(2-(4-(tert-Butyl)phenyl)-4-methylthiazol-5-yl)1,3,4-oxadiazol-2-yl)morpholine (18). Following the general procedure 4.2.1., and using morpholine (35 $\mu \mathrm{L}, 0.4 \mathrm{mmol}$ ), compound 18 was obtained as yellow solid $(0.098 \mathrm{~g}, 97 \%) \mathrm{mp}=$ $285{ }^{\circ} \mathrm{C} ;{ }^{1} \mathrm{H}$ NMR (DMSO- $\left.d_{6}\right) \delta: 7.99(\mathrm{~d}, J=8.4 \mathrm{~Hz}, 2 \mathrm{H}), 7.57(\mathrm{~d}, J$ $=8.4 \mathrm{~Hz}, 2 \mathrm{H}), 3.73(\mathrm{~m}, 4 \mathrm{H}), 3.48(\mathrm{~m}, 4 \mathrm{H}), 2.68(\mathrm{~s}, 3 \mathrm{H}), 1.32(\mathrm{~s}$, $9 \mathrm{H}) ;{ }^{13} \mathrm{C}$ NMR (DMSO- $d_{6}$ ) $\delta: 167.0,164.0,154.5,154.0,153.1$, 130.0, 126.6, 126.3, 114.7, 65.6, 46.2, 35.2, 31.3, 17.4; MS (m/z) 384; HRMS (EI) $m / z 384.1620 \mathrm{M}^{+}$, calcd for $\mathrm{C}_{20} \mathrm{H}_{24} \mathrm{~N}_{4} \mathrm{O}_{2} \mathrm{~S}$ 384.1620; anal. calc. for: $\left(\mathrm{C}_{20} \mathrm{H}_{24} \mathrm{~N}_{4} \mathrm{O}_{2} \mathrm{~S}\right): \mathrm{C}, 62.48 ; \mathrm{H}, 6.29 ; \mathrm{N}$, $14.57 \%$; found: C, 62.49; H, 6.30; N, 14.59\%

4.2.13. 2-(2-(4-(tert-Butyl)phenyl)-4-methylthiazol-5-yl)-5(4-methylpiperazin-1-yl)-1,3,4-oxadiazole (19). Following the general procedure 4.2.1., and using 4-methylpiperazine $(40 \mu \mathrm{L}$, $0.4 \mathrm{mmol})$, compound 19 was obtained as yellow solid $(0.099 \mathrm{~g}$, $97 \%) \mathrm{mp}=177{ }^{\circ} \mathrm{C} ;{ }^{1} \mathrm{H}$ NMR (DMSO- $\left.d_{6}\right) \delta: 7.84(\mathrm{~d}, J=8.4 \mathrm{~Hz}$, $2 \mathrm{H}), 7.52(\mathrm{~d}, J=8.4 \mathrm{~Hz}, 2 \mathrm{H}), 3.47(\mathrm{~m}, 4 \mathrm{H}), 2.66(\mathrm{~s}, 3 \mathrm{H}) 2.25(\mathrm{~m}$, $4 \mathrm{H}), 2.14(\mathrm{~s}, 3 \mathrm{H}), 1.28(\mathrm{~s}, 9 \mathrm{H}) ;{ }^{13} \mathrm{C}$ NMR (DMSO- $\left.d_{6}\right) \delta: 166.8$, 163.8, 161.8, 157.1, 156.4, 130.2, 126.6, 126.5, 114.7, 53.7, 46.0, 43.8, 35.1, 31.3, 17.5; MS (m/z) 397; HRMS (EI) $m / z 397.1936 \mathrm{M}^{+}$, calcd for $\mathrm{C}_{21} \mathrm{H}_{27} \mathrm{~N}_{5} \mathrm{OS} 397.1936$; anal. calc. for: $\left(\mathrm{C}_{21} \mathrm{H}_{27} \mathrm{~N}_{5} \mathrm{OS}\right): \mathrm{C}$, 63.45; H, 6.85; N, 17.62\%; found: C, 63.47; H, 6.87; N, 17.64\%.

4.2.14. 1-(5-(2-(4-(tert-Butyl)phenyl)-4-methylthiazol-5-yl)1,3,4-oxadiazol-2-yl)azetidin-3-ol (20). Following the general procedure 4.2.1., and using azetidin-3-ol hydrochloride $(0.04 \mathrm{~g}$, $0.4 \mathrm{mmol})$, compound 20 was obtained as yellow solid (0.05 g, $54 \%) \mathrm{mp}=210{ }^{\circ} \mathrm{C} ;{ }^{1} \mathrm{H}$ NMR (DMSO- $\left.d_{6}\right) \delta: 7.88(\mathrm{~d}, J=8.4 \mathrm{~Hz}$, $2 \mathrm{H}), 7.52(\mathrm{~d}, J=8.4 \mathrm{~Hz}, 2 \mathrm{H}), 6.06$ (brs, $1 \mathrm{H}), 4.66(\mathrm{~m}, 1 \mathrm{H}), 4.35$ (dd, $J=7.6 \mathrm{~Hz}, J=8.4 \mathrm{~Hz}, 2 \mathrm{H}), 3.97(\mathrm{dd}, J=5.2 \mathrm{~Hz}, J=8.2 \mathrm{~Hz}$, $2 \mathrm{H}), 2.65(\mathrm{~s}, 3 \mathrm{H}), 1.29(\mathrm{~s}, 9 \mathrm{H}) ;{ }^{13} \mathrm{C}$ NMR (DMSO- $\left.d_{6}\right) \delta: 166.9$, $164.7,154.49,154.45,154.42$, 129.9, 126.6, 126.4, 114.6, 62.3, 62.1, 35.1, 31.3, 17.4; MS (m/z) 370; HRMS (EI) $m / z 370.1463 \mathrm{M}^{+}$, calcd for $\mathrm{C}_{19} \mathrm{H}_{22} \mathrm{~N}_{4} \mathrm{O}_{2} \mathrm{~S} 370.1463$; anal. calc. for: $\left(\mathrm{C}_{19} \mathrm{H}_{22} \mathrm{~N}_{4} \mathrm{O}_{2} \mathrm{~S}\right)$ : C, 61.60; H, 5.99; N, 15.12\%; found: C, 61.61; H, 6.01; N, 15.13\%.

4.2.15. 2-(2-(4-(tert-Butyl)phenyl)-4-methylthiazol-5-yl)-5hydrazinyl-1,3,4-oxadiazole (21). Following the general procedure 4.2.1., and using hydrazine hydrate $(5 \mathrm{~mL})$, compound 21 was obtained as yellow fluffy powder $(0.06 \mathrm{~g}, 75 \%) \mathrm{mp}=260^{\circ} \mathrm{C}$; ${ }^{1} \mathrm{H}$ NMR (DMSO- $\left.d_{6}\right) \delta: 7.85(\mathrm{~d}, J=8.4 \mathrm{~Hz}, 2 \mathrm{H}), 7.50(\mathrm{~d}, J=8.4 \mathrm{~Hz}$, 2H), 6.94 (brs, 1H), 4.54 (brs, 2H), $2.62(\mathrm{~s}, 3 \mathrm{H}), 1.31(\mathrm{~s}, 9 \mathrm{H}) ;{ }^{13} \mathrm{C}$ NMR (DMSO- $d_{6}$ ) $\delta: 166.3,163.2,155.7,155.2,154.1,130.3$, 126.6, 126.5, 124.6, 35.1, 31.3, 17.5; MS (m/z) 329; HRMS (EI) $m / z$ 329.1310 $\mathrm{M}^{+}$, calcd for $\mathrm{C}_{16} \mathrm{H}_{19} \mathrm{~N}_{5} \mathrm{OS} 329.1310$; anal. calc. for: $\left(\mathrm{C}_{16} \mathrm{H}_{19} \mathrm{~N}_{5} \mathrm{OS}\right): \mathrm{C}, 58.34 ; \mathrm{H}, 5.81 ; \mathrm{N}, 21.26 \%$; found: $\mathrm{C}, 58.36 ; \mathrm{H}$, $5.82 ; \mathrm{N}, 21.26 \%$.
4.2.16. 1-(5-(2-(4-(tert-Butyl)phenyl)-4-methylthiazol-5-yl)1,3,4-oxadiazol-2-yl)guanidine (22). Following the general procedure 4.2.1., and using guanidine hydrochloride ( $0.05 \mathrm{~g}, 0.5$ $\mathrm{mmol}$ ), compound 22 was obtained as grayish solid (0.07 g, $76 \%) \mathrm{mp}=198{ }^{\circ} \mathrm{C} ;{ }^{1} \mathrm{H}$ NMR (DMSO- $\left.d_{6}\right) \delta: 7.88(\mathrm{~d}, J=8.4 \mathrm{~Hz}$, $2 \mathrm{H}), 7.53$ (d, $J=8.4 \mathrm{~Hz}, 2 \mathrm{H}), 7.21$ (brs, 1H), 7.06 (brs, 3H), 2.65 $(\mathrm{s}, 3 \mathrm{H}), 1.29$ (s, 9H); ${ }^{13} \mathrm{C}$ NMR (DMSO- $\left.d_{6}\right) \delta: 167.2,166.5,159.5$, 154.3, 153.7, 152.6, 130.0, 126.6, 126.5, 115.7, 35.1, 31.3, 17.3; MS (m/z) 356; HRMS (EI) $m / z 356.1419 \mathbf{M}^{+}$, calcd for $\mathrm{C}_{17} \mathrm{H}_{20} \mathrm{~N}_{6} \mathrm{OS}$ 356.1419; anal. calc. for: $\left(\mathrm{C}_{17} \mathrm{H}_{20} \mathrm{~N}_{6} \mathrm{OS}\right): \mathrm{C}, 57.28 ; \mathrm{H}, 5.66 ; \mathrm{N}$, $23.58 \%$; found: $\mathrm{C}, 57.30 ; \mathrm{H}, 5.67 ; \mathrm{N}, 23.60 \%$.

4.2.17. 1-(5-(2-(4-(tert-Butyl)phenyl)-4-methylthiazol-5-yl)1,3,4-oxadiazol-2-yl)-3-methylguanidine (23). Following the general procedure 4.2.1., and using methylguanidine hydrochloride ( $0.06 \mathrm{~g}, 0.5 \mathrm{mmol}$ ), compound 23 was obtained as yellowish brown solid $(0.07 \mathrm{~g}, 75 \%) \mathrm{mp}=194{ }^{\circ} \mathrm{C} ;{ }^{1} \mathrm{H} \mathrm{NMR}$ $\left(\right.$ DMSO$\left._{-} d_{6}\right) \delta: 7.89$ (d, $\left.J=8.4 \mathrm{~Hz}, 2 \mathrm{H}\right), 7.81$ (brs, 1H), $7.54(\mathrm{~d}, J=$ $8 \mathrm{~Hz}, 2 \mathrm{H}), 7.37$ (brs, 1H), 2.87 (s, 3H), 2.78 (brs, 1H), $2.67(\mathrm{~s}, 3 \mathrm{H})$, $1.30(\mathrm{~s}, 9 \mathrm{H}) ;{ }^{13} \mathrm{C}$ NMR (DMSO- $\left.d_{6}\right) \delta: 166.5,164.2,154.3,153.8$, 153.0, 130.1, 130.0, 126.6, 126.5, 115.0, 35.1, 31.3, 29.5, 17.4; MS $(m / z) 370$; HRMS (EI) $m / z 370.1576 \mathbf{M}^{+}$, calcd for $\mathrm{C}_{18} \mathrm{H}_{22} \mathrm{~N}_{6} \mathrm{OS}$ 370.1576; anal. calc. for: $\left(\mathrm{C}_{18} \mathrm{H}_{22} \mathrm{~N}_{6} \mathrm{OS}\right): \mathrm{C}, 58.36 ; \mathrm{H}, 5.99 ; \mathrm{N}$, $22.68 \%$; found: C, 58.37 ; H, 5.99; N, 22.69\%.

4.2.18. 3-(5-(2-(4-(tert-Butyl)phenyl)-4-methylthiazol-5-yl)1,3,4-oxadiazol-2-yl)-1,1-dimethylguanidine (24). Following the general procedure 4.2.1., and using 1,1-dimethylguanidine hydrochloride $(0.06 \mathrm{~g}, 0.5 \mathrm{mmol})$, compound 24 was obtained as yellowish brown solid $(0.08 \mathrm{~g}, 75 \%) \mathrm{mp}=194{ }^{\circ} \mathrm{C} ;{ }^{1} \mathrm{H} \mathrm{NMR}$ $\left(\right.$ DMSO$\left.d_{6}\right) \delta: 7.89(\mathrm{~d}, J=8.4 \mathrm{~Hz}, 2 \mathrm{H}), 7.75$ (brs, 2H), 7.54 (d, $J=$ $8 \mathrm{~Hz}, 2 \mathrm{H}), 3.01(\mathrm{~s}, 6 \mathrm{H}), 2.68(\mathrm{~s}, 3 \mathrm{H}), 1.29(\mathrm{~s}, 9 \mathrm{H}) ;{ }^{13} \mathrm{C}$ NMR $\left(\mathrm{DMSO}-d_{6}\right) \delta: 166.8,166.6,157.8,154.3,153.9,152.8,130.1$, 126.63, 126.60, 115.7, 37.5, 35.1, 31.3, 17.5; MS ( $m / z) 384$; HRMS (EI) $m / z 384.1732 \mathrm{M}^{+}$, calcd for $\mathrm{C}_{19} \mathrm{H}_{24} \mathrm{~N}_{6} \mathrm{OS} 384.1732$; anal. calc. for: $\left(\mathrm{C}_{19} \mathrm{H}_{24} \mathrm{~N}_{6} \mathrm{OS}\right)$ : C, 59.35; H, 6.29; N, 21.86\%; found: C, 59.35; $\mathrm{H}, 6.29$; N, $21.86 \%$.

4.2.19. 2-(5-(2-(4-(tert-Butyl)phenyl)-4-methylthiazol-5-yl)1,3,4-oxadiazol-2-yl)-1,1,3,3-tetramethylguanidine Following the general procedure 4.2.1., and using $N, N$-tetramethyl guanidine $(50 \mu \mathrm{L}, 0.4 \mathrm{mmol})$, compound 25 was obtained as yellowish brown solid $(0.08 \mathrm{~g}, 75 \%) \mathrm{mp}=194{ }^{\circ} \mathrm{C} ;{ }^{1} \mathrm{H}$ NMR (DMSO- $\left.d_{6}\right) \delta: 7.88(\mathrm{~d}, J=8.4 \mathrm{~Hz}, 2 \mathrm{H}), 7.52(\mathrm{~d}, J=8.4 \mathrm{~Hz}$, $2 \mathrm{H}), 2.81(\mathrm{~s}, 12 \mathrm{H}), 2.66(\mathrm{~s}, 3 \mathrm{H}), 1.28(\mathrm{~s}, 9 \mathrm{H}) ;{ }^{13} \mathrm{C}$ NMR (DMSO- $\left.d_{6}\right)$ $\delta: 166.4,164.9,163.7,154.2,154.1,153.4,130.1,126.6,126.5$, 115.8, 139.3, 35.1, 31.3, 17.4; MS $(\mathrm{m} / \mathrm{z})$ 412; HRMS (EI) $\mathrm{m} / \mathrm{z}$ 412.2045 $\mathrm{M}^{+}$, calcd for $\mathrm{C}_{21} \mathrm{H}_{28} \mathrm{~N}_{6} \mathrm{OS}$ 412.2045; anal. calc. for: $\left(\mathrm{C}_{21} \mathrm{H}_{28} \mathrm{~N}_{6} \mathrm{OS}\right): \mathrm{C}, 61.14 ; \mathrm{H}, 6.84 ; \mathrm{N}, 20.37 \%$; found: $\mathrm{C}, 61.15 ; \mathrm{H}$, $6.86 ; \mathrm{N}, 20.38 \%$.

4.2.20. $\quad \mathrm{N}$-(5-(2-(4-(tert-Butyl)phenyl)-4-methylthiazol-5-yl)1,3,4-oxadiazol-2-yl)morpholine-4-carboximidamide

Following the general procedure 4.2.1., and using morpholine4-carboximidamide hydroiodide $(0.1 \mathrm{~g}, 0.4 \mathrm{mmol})$, compound 26 was obtained as yellow solid $(0.07 \mathrm{~g}, 65 \%) \mathrm{mp}=260{ }^{\circ} \mathrm{C} ;{ }^{1} \mathrm{H}$ NMR (DMSO- $\left.d_{6}\right) \delta$ : 7.96 (brs, 2H), $7.90(\mathrm{~d}, J=8.4 \mathrm{~Hz}, 2 \mathrm{H}), 7.54$ $(\mathrm{d}, J=8.4 \mathrm{~Hz}, 2 \mathrm{H}), 3.64(\mathrm{~m}, 4 \mathrm{H}), 3.56(\mathrm{~m}, 4 \mathrm{H}), 2.69(\mathrm{~s}, 3 \mathrm{H}), 1.31$ $(\mathrm{s}, 9 \mathrm{H}) ;{ }^{13} \mathrm{C}$ NMR (DMSO- $\left.d_{6}\right) \delta: 166.9,166.8,157.2,154.3,154.1$, 153.2, 130.0, 126.6, 126.5, 115.4, 66.1, 44.8, 35.1, 31.3, 17.5; MS 
$(\mathrm{m} / z)$ 426; HRMS (EI) $m / z 426.1838 \mathrm{M}^{+}$, calcd for $\mathrm{C}_{21} \mathrm{H}_{26} \mathrm{~N}_{6} \mathrm{O}_{2} \mathrm{~S}$ 426.1838; anal. calc. for: $\left(\mathrm{C}_{21} \mathrm{H}_{26} \mathrm{~N}_{6} \mathrm{O}_{2} \mathrm{~S}\right): \mathrm{C}, 59.13 ; \mathrm{H}, 6.14 ; \mathrm{N}$, $19.70 \%$; found: C, $59.15 ; \mathrm{H}, 6.15 ; \mathrm{N}, 19.72 \%$.

4.2.21. $\quad N$-(5-(2-(4-(tert-Butyl)phenyl)-4-methylthiazol-5-yl)1,3,4-oxadiazol-2-yl)-4-methylpiperazine-1-carboximidamide (27). Following the general procedure 4.2.1., and using 4methylpiperazine-1-carboximidamide hydroiodide $(0.11 \mathrm{~g}, 0.4$ $\mathrm{mmol}$ ), compound 27 was obtained as yellow solid (0.07 g, 63\%) $\mathrm{mp}=262{ }^{\circ} \mathrm{C} ;{ }^{1} \mathrm{H}$ NMR (DMSO- $\left.d_{6}\right) \delta: 7.98(\mathrm{brs}, 2 \mathrm{H}), 7.92(\mathrm{~d}, J=$ $8.4 \mathrm{~Hz}, 2 \mathrm{H}), 7.52(\mathrm{~d}, J=8.4 \mathrm{~Hz}, 2 \mathrm{H}), 3.58(\mathrm{~m}, 4 \mathrm{H}), 2.68(\mathrm{~s}, 3 \mathrm{H})$, $2.35(\mathrm{~m}, 4 \mathrm{H}), 2.21(\mathrm{~s}, 3 \mathrm{H}), 1.30(\mathrm{~s}, 9 \mathrm{H}) ;{ }^{13} \mathrm{C}$ NMR (DMSO- $\left.d_{6}\right) \delta$ : 166.9, 166.6, 156.9, 154.3, 154.0, 153.0, 130.0, 126.59, 126.56, 115.5, 54.5, 45.9, 44.3, 35.1, 31.3, 17.5; MS (m/z) 439; HRMS (EI) $m / z$ 439.2154 $\mathrm{M}^{+}$, calcd for $\mathrm{C}_{22} \mathrm{H}_{29} \mathrm{~N}_{7} \mathrm{OS} 439.2154$; anal. calc. for: $\left(\mathrm{C}_{22} \mathrm{H}_{29} \mathrm{~N}_{7} \mathrm{OS}\right): \mathrm{C}, 60.11 ; \mathrm{H}, 6.65 ; \mathrm{N}, 22.31 \%$; found: $\mathrm{C}, 60.12 ; \mathrm{H}$, $6.67 ; \mathrm{N}, 22.33 \%$.

4.2.22. $\quad N-(5-(2-(4-($ tert-Butyl)phenyl)-4-methylthiazol-5-yl)1,3,4-oxadiazol-2-yl)picolinimidamide (28). Following the general procedure 4.2.1., and using picolinimidamide hydrochloride (0.06 g, $0.4 \mathrm{mmol}$ ), compound 28 was obtained as yellow solid $(0.1 \mathrm{~g}, 91 \%) \mathrm{mp}=225{ }^{\circ} \mathrm{C} ;{ }^{1} \mathrm{H}$ NMR (DMSO- $\left.d_{6}\right) \delta$ : 9.43 (brs, 1H), 8.92 (brs, 1H), 8.76 (m, 1H), 8.34 (m, 1H), 7.94$7.82(\mathrm{~m}, 3 \mathrm{H}), 7.57-7.49(\mathrm{~m}, 3 \mathrm{H}), 2.68(\mathrm{~s}, 3 \mathrm{H}), 1.30(\mathrm{~s}, 9 \mathrm{H}) ;{ }^{13} \mathrm{C}$ NMR (DMSO- $d_{6}$ ) $\delta: 167.2,166.9,162.8,158.4,158.0,154.2$, 153.9, 149.0, 138.0, 131.7, 130.5, 126.5, 126.4, 122.6, 111.4, 35.1, 31.3, 18.7; MS (m/z) 418; HRMS (EI) $\mathrm{m} / z$ 418.1576 $\mathrm{M}^{+}$, calcd for $\mathrm{C}_{22} \mathrm{H}_{22} \mathrm{~N}_{6} \mathrm{OS} 418.1576$; anal. calc. for: $\left(\mathrm{C}_{22} \mathrm{H}_{22} \mathrm{~N}_{6} \mathrm{OS}\right)$ : C, 63.14; $\mathrm{H}$, 5.30 ; N, 20.08\%; found: C, 63.15; H, 5.31; N, 20.09\%.

4.2.23. $\quad N-(5-(2-(4-($ tert-Butyl)phenyl)-4-methylthiazol-5-yl)1,3,4-oxadiazol-2-yl)nicotinimidamide (29). Following the general procedure 4.2.1., and using nicotinimidamide hydrochloride ( $0.06 \mathrm{~g}, 0.4 \mathrm{mmol})$, compound 29 was obtained as yellow solid $(0.1 \mathrm{~g}, 91 \%) \mathrm{mp}=289{ }^{\circ} \mathrm{C} ;{ }^{1} \mathrm{H}$ NMR (DMSO- $\left.d_{6}\right) \delta: 9.78$ (brs, $1 \mathrm{H}), 9.24(\mathrm{~s}, 1 \mathrm{H}), 9.02(\mathrm{brs}, 1 \mathrm{H}), 8.75(\mathrm{~d}, J=6.8 \mathrm{~Hz}, 1 \mathrm{H}), 8.46(\mathrm{t}, J=$ $6.6 \mathrm{~Hz}, 1 \mathrm{H}), 7.95(\mathrm{~d}, J=8.4 \mathrm{~Hz}, 2 \mathrm{H}), 7.56(\mathrm{~m}, 3 \mathrm{H}), 2.71(\mathrm{~s}, 3 \mathrm{H})$, 1.28 (s, 9H); ${ }^{13} \mathrm{C}$ NMR (DMSO- $\left.d_{6}\right) \delta: 167.6,166.4,160.5,155.4$, 155.1, 154.5, 152.8, 149.2, 135.9, 130.6, 129.6, 126.5, 126.4, 123.9, 114.8, 35.1, 31.3, 17.6; MS (m/z) 418; HRMS (EI) $m / z 418.1576 \mathrm{M}^{+}$, calcd for $\mathrm{C}_{22} \mathrm{H}_{22} \mathrm{~N}_{6} \mathrm{OS} 418.1576$; anal. calc. for: $\left(\mathrm{C}_{22} \mathrm{H}_{22} \mathrm{~N}_{6} \mathrm{OS}\right)$ : C, 63.14; H, 5.30; N, 20.08\%; found: C, 63.16; H, 5.32; N, 20.10\%.

4.2.24. $\quad N$-(5-(2-(4-(tert-Butyl)phenyl)-4-methylthiazol-5-yl)1,3,4-oxadiazol-2-yl)isonicotinimidamide (30). Following the general procedure 4.2.1., and using isonicotinimidamide hydrochloride ( $0.06 \mathrm{~g}, 0.4 \mathrm{mmol})$, compound 30 was obtained as yellow solid $(0.07 \mathrm{~g}, 64 \%) \mathrm{mp}=257{ }^{\circ} \mathrm{C} ;{ }^{1} \mathrm{H}$ NMR (DMSO- $\left.d_{6}\right) \delta: 9.83$ (brs, 1H), 9.05 (brs, $1 \mathrm{H}), 8.77$ (d, $J=7.6 \mathrm{~Hz}, 2 \mathrm{H}), 7.89$ (d, $J=7.6 \mathrm{~Hz}$, $2 \mathrm{H}), 7.83(\mathrm{~d}, J=8.4 \mathrm{~Hz}, 2 \mathrm{H}), 7.52(\mathrm{~d}, J=8.4 \mathrm{~Hz}, 2 \mathrm{H}), 2.73(\mathrm{~s}, 3 \mathrm{H})$, 1.29 (s, 9H); ${ }^{13} \mathrm{C}$ NMR (DMSO- $d_{6}$ ) $\delta: 167.7,166.3,160.2,155.5$, 154.5, 153.9, 150.7, 141.1, 130.0, 126.6, 126.4, 121.9, 114.7, 35.1, 31.2, 17.6; MS (m/z) 418; HRMS (EI) $\mathrm{m} / z 418.1576 \mathrm{M}^{+}$, calcd for

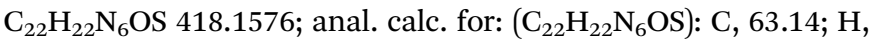
5.30 ; N, 20.08\%; found: C, 63.16; H, 5.31; N, 20.09\%.

\subsection{Microbiological assays}

4.3.1. Determination of minimum inhibitory concentration (MIC) and minimum bactericidal concentration (MBC).
Broth microdilution method was used ${ }^{\mathbf{1 8 , 1 9}}$ against a panel of clinically important Gram positive bacterial pathogens according the previous reports. ${ }^{19,20}$

4.3.2. Time-kill assay against MRSA. It was performed against MRSA USA400 as described previously. ${ }^{\mathbf{2 0 , 2 1}}$ In brief, bacterial cells in logarithmic phase were diluted and drugs were added at $5 \times$ MIC and $10 \times$ MIC (in triplicates). After time points, cells were collected, diluted and plated on tryptic soy agar plates. Plates were incubated for 18-20 hours and the viable CFU $\mathrm{mL}^{-1}$ was determined.

4.3.3. MRSA biofilm eradication assessment. Compound 20 was examined for its ability to eradicate established, mature staphylococcal biofilm using the microtiter plate biofilm formation assay following the procedure described before. ${ }^{7,22,23}$

4.3.4. In vivo pharmacokinetics. Pharmacokinetic studies were performed following the procedure described in a previous report. $^{5}$

\section{Conflicts of interest}

There are no conflicts to declare.

\section{Acknowledgements}

This work was funded by Science \& Technology Development Funds (STDF-Egypt) and the Egyptian Ministry of Higher Education and Scientific Research (MHESR). The work is derived from the Subject Data funded in whole or part by NAS and USAID, and that any opinions, findings, conclusions, or recommendations expressed in such article are those of the authors alone, and do not necessarily reflect the views of USAID or NAS. The authors would like to thank BEI Resources for providing clinical isolates of $S$. aureus used in this study.

\section{Notes and references}

1 M. Hagras, Y. A. Hegazy, A. H. Elkabbany, H. Mohammad, A. Ghiaty, T. M. Abdelghany, M. N. Seleem and A. S. Mayhoub, Eur. J. Med. Chem., 2018, 143, 1448-1456.

2 H. Mohammad, A. S. Mayhoub, A. Ghafoor, M. Soofi, R. A. Alajlouni, M. Cushman and M. N. Seleem, J. Med. Chem., 2014, 57, 1609-1615.

3 H. Mohammad, W. Younis, L. Chen, C. E. Peters, J. Pogliano, K. Pogliano, B. Cooper, J. Zhang, A. Mayhoub, E. Oldfield, M. Cushman and M. N. Seleem, J. Med. Chem., 2017, 60, 2425-2438.

4 M. Hagras, H. Mohammad, M. S. Mandour, Y. A. Hegazy, A. Ghiaty, M. N. Seleem and A. S. Mayhoub, J. Med. Chem., 2017, 60, 4074-4085.

5 M. A. Seleem, A. M. Disouky, H. Mohammad, T. M. Abdelghany, A. S. Mancy, S. A. Bayoumi, A. Elshafeey, A. El-Morsy, M. N. Seleem and A. S. Mayhoub, J. Med. Chem., 2016, 59, 4900-4912.

6 E. Yahia, H. Mohammad, T. M. Abdelghany, E. Fayed, M. N. Seleem and A. S. Mayhoub, Eur. J. Med. Chem., 2017, 126, 604-613. 
7 A. Kotb, N. S. Abutaleb, M. A. Seleem, M. Hagras, H. Mohammad, A. Bayoumi, A. Ghiaty, M. N. Seleem and A. S. Mayhoub, Eur. J. Med. Chem., 2018, 151, 110-120.

8 I. Eid, M. M. Elsebaei, H. Mohammad, M. Hagras, C. E. Peters, Y. A. Hegazy, B. Cooper, J. Pogliano, K. Pogliano, H. S. Abulkhair, M. N. Seleem and A. S. Mayhoub, Eur. J. Med. Chem., 2017, 139, 665-673.

9 H. Mohammad, A. AbdelKhalek, N. S. Abutaleb and M. N. Seleem, Int. J. Antimicrob. Agents, 2018, 51, 897-904.

10 A. AbdelKhalek, N. S. Abutaleb, K. A. Elmagarmid and M. N. Seleem, Sci. Rep., 2018, 8, 8353.

11 A. AbdelKhalek, N. S. Abutaleb, H. Mohammad and M. N. Seleem, PLoS One, 2018, 13, e0199710.

12 R. J. McLean, J. S. Lam and L. L. Graham, J. Bacteriol., 2012, 194, 6706-6711.

13 R. Cavaliere, J. L. Ball, L. Turnbull and C. B. Whitchurch, MicrobiologyOpen, 2014, 3, 557-567.

14 R. Wang, B. A. Khan, G. Y. Cheung, T. H. Bach, M. JamesonLee, K. F. Kong, S. Y. Queck and M. Otto, J. Clin. Invest., 2011, 121, 238-248.
15 D. Davies, Nat. Rev. Drug Discovery, 2003, 2, 114-122.

16 L. D. Saravolatz, G. E. Stein and L. B. Johnson, Clin. Infect. Dis., 2011, 52, 1156-1163.

17 C. R. Caulder, A. Sloan, A. Yasir and P. B. Bookstaver, Hosp. Pharm., 2014, 49, 644-646.

18 S. Thangamani, H. Mohammad, M. F. Abushahba, T. J. Sobreira, V. E. Hedrick, L. N. Paul and M. N. Seleem, Sci. Rep., 2016, 6, 22571.

19 H. Mohammad, M. Cushman and M. N. Seleem, PLoS One, 2015, 10, e0130385.

20 M. F. Mohamed, M. I. Hamed, A. Panitch and M. N. Seleem, Antimicrob. Agents Chemother., 2014, 58, 4113-4122.

21 M. F. Mohamed, G. K. Hammac, L. Guptill and M. N. Seleem, PLoS One, 2014, 9, e116259.

22 G. A. O'Toole, J. Visualized Exp., 2011, 47, 2437.

23 H. Mohammad, A. S. Mayhoub, M. Cushman and M. N. Seleem, J. Antibiot., 2015, 68, 259-266. 